\title{
Peertechz
}

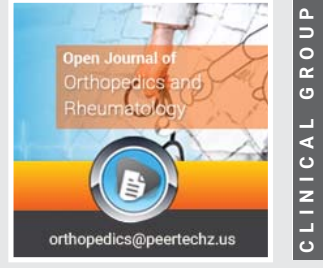

Research Article

\section{Association of different} Demographic characteristics with Hip Osteoarthritis patients attending the

\section{different Hospitals across the Karachi and Quetta}

\section{Aadil Ameer Ali*, Natasha Bhutto', Shahmeer Chandio', Shoaib Waqas ${ }^{2}$, Ali Raza Khoso ${ }^{3}$, Muhammad Rafique ${ }^{4}$, Muhammad Ismail ${ }^{4}$ and Shanza Iqbal ${ }^{5}$}

${ }^{1}$ Institute of Physiotherapy \& Rehabilitation Sciences, Shaheed Mohtarma Benazir Bhutto Medical University, Larkana, Pakistan

${ }^{2}$ Lahore College of Physical Therapy, Lahore Medical \& Dental College, Lahore, Pakistan

${ }^{3}$ Institute of Physiotherapy \& Rehabilitation Sciences, Liaquat University of Medical \& Health Sciences, Jamshoro, Pakistan

${ }^{4}$ Department of Statistics, University of Sindh, Jamshoro, Pakistan

${ }^{5}$ Helping Hands for relief and Development, Quetta, Pakistan
Received: 27 July, 2021

Accepted: 07 September, 2021

Published: 08 September, 2021

*Corresponding author: Dr. Aadil Ameer Ali, Lecturer Physiotherapy, Institute of Physiotherapy \& Rehabilitation Sciences, Shaheed Mohtarma Benazir Bhutto Medical University, Larkana, Pakistan, Tel: +923002929464; E-mail: aadilamirali@hotmail.com

Keywords: Demographic characteristics; Hip osteoarthritis; Karachi \& Quetta; Pakistan

https://www.peertechzpublications.com

\section{Check for updates}

\begin{abstract}
Hip osteoarthritis (OA) is the most frequent and common among all degenerative joint disorders and affecting huge number of individuals. Older females and low income people are more likely to develop Hip OA. A cross sectional survey was conducted in different hospitals of Karachi \& Quetta, Pakistan from July to September 2019. A self-constructed proforma was used among all 392 already diagnosed patients to collect the data and Spss version 23 was used to analyze the data. In demographic Characterstics the age, gender and household income were significantly associated with Hip OA ( $<<0.05)$. The study concluded that the people who were older, belongs to female gender and with low house hold income were found physically restrictive due to the hip OA. Older females and people with low income should be prioritized for the treatment of hip OA in order to reduce the restrictiveness from their activities of daily life and to enhance their physical functional capacity.
\end{abstract}

\section{Introduction}

Osteoarthritis $(\mathrm{OA})$ is the most common age related joint disorder among all degenerative joint disorders and a major cause of chronic disability throughout the world. Primary osteoarthritis is idiopathic and more common in females, it involves Fingers, spine, hips, and knees, while the secondary osteoarthritis involves the joint due to trauma or repetitive injury. Hip joint is one of the most effected joint because OA commonly involves the weight bearing joints. OA is characterized by the progressive loss of bone \& cartilage of the joints $[1,2]$. The risk factors for the Hip OA are joint injury, increasing age and being overweight. In addition, osteoarthritis can sometimes be caused by other factors which are osteogenic, neurogenic, myogenic and hormonal as well. The Bilateral OA is mostly genetically determined and the Women are susceptible 
to develop hip OA because of osteoporosis which is strongly correlated to progressive skeletal muscular and ligamentous weakness and redundancy $[1,3,4]$.

After the age of 40 years the prevalence OA increases, in people with 65 years of age OA accounts for $75 \%$ and it progresses as patient ages. In Pakistan, $26 \%$ from urban and $25 \%$ population from rural areas are affected with Hip OA. Hip OA appears with pain, discomfort, morning stiffness, and inflammation especially with physical disability of lower extremities, the severity and disability increases as the person ages. Risk factors for the Hip OA are age, gender, obesity, injury, genetics, anatomy and smoking [5-8].

\section{Methods}

\section{Study design, settings and duration}

A cross sectional survey was conducted from July to September 2019 and data was collected from different hospitals of Karachi \& Quetta Pakistan (Jinnah postgraduate medical Centre Karachi, Sandeman Provincial Hospital, Hope Physiotherapy Centre, and Akram Hospital Quetta).

\section{Sampling}

Convenient Non-Probability Sampling Technique was used among 392 patients who were included from above mention hospital and were agreed to participate in the study. Patients were included with confirmed diagnosis of Hip OA, both genders \& should understand the Urdu language (National language of Pakistan). While, Patient with rheumatoid arthritis or any other inflammatory disease, Hip replacement, any surgical intervention, central nervous system alteration, malignancy or unwilling to sign inform consent were excluded.

\section{Data collection tool}

A proforma was used to collect the data, which include the demographic Characterstics (age, gender, marital status, education, occupation, income and locality) while the included clinical characteristics were severity (mild, moderate, severe and not able to move) which was measured through the visual analogue scale [9] along with radiological evaluation [10]. The involvement of the part was described as unilateral (involving one side) or Bilateral (involving both sides) and the use of medications by the patients were asked too.

\section{Data collection procedure}

During the assessment of patient, the trained physical therapists were asked to fill the proforma.

\section{Data analysis procedure}

Data was analyzed and presented in frequency and percentages for categorical variables, mean and standard deviations were presented for continuous variables. Inferential statistics (chi-square test) was used to identify relationship between different demographic \& clinical Characterstics.

\section{Ethical consideration}

As the approval was taken from the ethical review committee of Faculty of Pharmacy \& Health Sciences, University of Balochistan, Quetta, Pakistan. Respectively Approval for the data collection was taken from medical superintendent of concerned hospitals. Informed consent was taken from patient containing that their participation is voluntary, their information will be kept confidential and they can leave the study anytime, after that the proforma was filled for data collection.

\section{Results}

\section{Demographic characterstics}

Demographic Characterstics are described in Table 1, which says that majority $(n=241,61.5 \%)$ belongs to age group between 53 to 62 years, and were male $(n=249,63.5 \%)$. After checking

Table 1: Demographic Characterstics.

\begin{tabular}{|c|c|c|}
\hline Characterstics & Frequency & Percentage \\
\hline \multicolumn{3}{|l|}{ Age group } \\
\hline $43-52$ years & 61 & 15.6 \\
\hline $53-62$ years & 241 & 61.5 \\
\hline 63 and more & 90 & 23.0 \\
\hline \multicolumn{3}{|l|}{ Gender } \\
\hline Male & 249 & 63.5 \\
\hline Female & 143 & 36.5 \\
\hline \multicolumn{3}{|l|}{ Marital status } \\
\hline Married & 322 & 82.1 \\
\hline Unmarried & 70 & 17.9 \\
\hline \multicolumn{3}{|l|}{ Education } \\
\hline Uneducated & 65 & 16.6 \\
\hline Religious education & 41 & 10.5 \\
\hline Primary education & 36 & 9.2 \\
\hline Matriculation & 50 & 12.8 \\
\hline Intermediate & 54 & 13.8 \\
\hline Bachelors & 90 & 23.0 \\
\hline Higher education & 56 & 14.3 \\
\hline \multicolumn{3}{|l|}{ Occupation } \\
\hline Government servant & 92 & 23.5 \\
\hline Private & 74 & 18.9 \\
\hline Un employed & 42 & 10.7 \\
\hline Self employed & 86 & 21.6 \\
\hline House wife & 98 & 25.0 \\
\hline \multicolumn{3}{|l|}{ Income } \\
\hline No income & 126 & 32.1 \\
\hline Won't disclose & 51 & 13.0 \\
\hline Less than 10,000 & 20 & 5.1 \\
\hline 10,000 to 20,000 & 56 & 14.3 \\
\hline 20,000 to 30,000 & 47 & 12.0 \\
\hline More then 30,000 & 92 & 23.5 \\
\hline \multicolumn{3}{|l|}{ Locality } \\
\hline Urban & 258 & 65.8 \\
\hline Rural & 134 & 34.2 \\
\hline
\end{tabular}

Citation: Ali AA, Bhutto N, Chandio S, Waqas S, Khoso AR, et al. (2021) Association of different Demographic characteristics with Hip Osteoarthritis patients attending the different Hospitals across the Karachi and Quetta. Open J Orthop Rheumatol 6(1): 062-066. DOI: https://dx.doi.org/10.17352/ojor.00040 
the educational status of patients majority $(n=90,23.0 \%)$ had bachelors and ( $\mathrm{n}=98,25.0 \%)$ were housewives. According to the income resources majority $(n=126,32.1 \%)$ had no income, and $(n=258,65.8 \%)$ belonged to urban areas.

\section{Disease characterstics}

Disease Characterstics are described in Table 2, in which severity was classified into mild, moderate, Severe and not able to move, the majority $(n=255,65.1 \%)$ were Severe, suffering with unilateral Hip OA $(n=349,89.0 \%)$ and $(n=370,94.4 \%)$ were using medication.

\section{Comparison of demographic characteristics vs Disease characteristics}

The comparison of demographic data with disease characteristics are described in Table 3, which states that the age group, gender and income are statically significant $(\mathrm{p}<0.05)$.

\section{Comparison of demographic data vs involvement of part}

The comparison of demographic data with involvement of part are described in Table 4, which states that age group and gender are statically significant $(\mathrm{p}<0.05)$ with the involvement of part

\section{Discussion}

The current study disclosed that there was a significant relationship between Hip osteoarthritis (OA) and demographic Characterstics (age, gender \& income), the results of the current study were in line with study reported by Cross $M$, et al in 2014 concluded that age, gender and income had a significant impact on Hip OA $[7,11]$.

Age is one of the major contributing factors in Hip OA. A Study reported by Anderson et al in 2010 that Patients with older age are on greatest risk for hip OA. Similarly studies from different part of the world (i.e Australia \& United States) concluded that the increase in age have greatest effects on Hip $\mathrm{OA}$ and experience more restrictiveness in activities of daily

\section{Table 2: Disease Characterstics.}

\begin{tabular}{|c|c|c|}
\hline Variable & Frequency & Percentage \\
\hline Severity & & \\
\hline Mild & 13 & 3.3 \\
\hline Moderate & 115 & 29.3 \\
\hline Severe & 255 & 65.1 \\
\hline Not able to move & 9.0 & 2.3 \\
\hline Involvement of Hip & & \\
\hline Unilateral & 349 & 89 \\
\hline Bilateral & 43 & 11 \\
\hline Medication & & 94.4 \\
\hline Yes & 22 & 5.6 \\
\hline No & 370 & \\
\hline
\end{tabular}

Table 3: Comparison of demographic characteristics vs Disease characteristics.

\begin{tabular}{|c|c|c|c|c|c|}
\hline Variable & $\begin{array}{l}\text { Mild } \\
\text { n (\%) }\end{array}$ & $\begin{array}{c}\text { Modrate } \\
\text { n (\%) }\end{array}$ & $\begin{array}{c}\text { Severe } \\
\text { n (\%) }\end{array}$ & $\begin{array}{c}\text { Notable to } \\
\text { move } \\
\text { n (\%) }\end{array}$ & $P$ value \\
\hline \multicolumn{5}{|l|}{ Age group } & \multirow{4}{*}{0.001} \\
\hline $43-52$ years & -- & $22(36.0)$ & $39(63.9)$ & -- & \\
\hline $53-62$ years & 12(4.9) & $71(29.4)$ & $151(62.6)$ & $07(2.9)$ & \\
\hline 63 and more & $01(1.1)$ & $22(24.4)$ & $65(72.2)$ & $02(2.2)$ & \\
\hline \multicolumn{5}{|l|}{ Gender } & \multirow{3}{*}{0.007} \\
\hline Male & $08(3.21)$ & $72(28.9)$ & 164(65.8) & $05(2.0)$ & \\
\hline Female & $05(3.49)$ & $43(30.0)$ & $91(63.6)$ & $04(2.79)$ & \\
\hline \multicolumn{5}{|l|}{ Marital Status } & \multirow{3}{*}{0.186} \\
\hline Married & 12(3.72) & $89(27.6)$ & 212(65.8) & $09(2.79)$ & \\
\hline Unmarried & $01(1.42)$ & $26(37.1)$ & $43(61.4)$ & --- & \\
\hline \multicolumn{5}{|l|}{ Education } & \multirow{8}{*}{0.290} \\
\hline Uneducated & $01(1.5)$ & $21(32.3)$ & $42(64.6)$ & $01(1.53)$ & \\
\hline Religious education & $01(2.43)$ & $11(26.8)$ & 29(70.7) & ----- & \\
\hline Primary education & $03(8.3)$ & 12(33.3) & $20(55.5)$ & 01(2.7) & \\
\hline Matriculation & $02(4.0)$ & $16(32.0)$ & $30(60.0)$ & $02(4.0)$ & \\
\hline Intermediate & $03(5.5)$ & $20(37.0)$ & $31(57.4)$ & $----)$ & \\
\hline Bachelors & $02(2.2)$ & $25(27.7)$ & $62(68.8)$ & $01(1.1)$ & \\
\hline Higher & $01(1.5)$ & $10(17.8)$ & $41(73.2)$ & $04(7.14)$ & \\
\hline Occupation & & & & & \\
\hline Government servant & $01(1.0)$ & $23(25.0)$ & $66(71.7)$ & $02(2.1)$ & \\
\hline Private & $03(4.0)$ & $26(35.1)$ & $42(56.7)$ & $03(4.0)$ & 0.47 \\
\hline Un employed & $01(2.3)$ & $17(40.4)$ & $24(57.1)$ & -- & 0.41 \\
\hline Self employed & $05(5.8)$ & $24(27.9)$ & $56(65)$ & 01(1.1) & \\
\hline House wife & $03(3.0)$ & $25(25.5)$ & $67(68.3)$ & 03(3.0) & \\
\hline Income & & & & & \\
\hline No income & $04(3.17)$ & $39(30.9)$ & $80(63.4)$ & $03(2.3)$ & \\
\hline Won't disclose & $01(1.9)$ & 10(19.6) & $39(76.4)$ & 01(1.96) & \\
\hline Less than 10,000 & $02(10.0)$ & $07(35.0)$ & $11(55.0)$ & -- & 0.001 \\
\hline 10,000 to 20,000 & $05(8.9)$ & $22(39.2)$ & $29(51.7)$ & -- & \\
\hline 20,000 to 30,000 & $01(2.0)$ & $11(22.9)$ & $35(72.9)$ & $01(2.0)$ & \\
\hline More than 30,000 & $01(1.08)$ & $26(28.2)$ & $61(66.3)$ & $04(4.3)$ & \\
\hline Locality & & & & & \\
\hline Urban & $07(2.71)$ & $81(31.3)$ & 165(63.9) & 05(1.93) & 0.479 \\
\hline Rural & $06(4.47)$ & $34(25.3)$ & $90(67.1)$ & $04(2.9)$ & \\
\hline
\end{tabular}

life. Within the context, it is stated that people with old age are more prone to develop Hip due to the detoriation of articular cartilages inside the knee joint $[6,7,12]$.

Gender is the second major contributing factor in hip OA and concluded that as compare to men in women symptoms are worsen, Furthermore, the women are more likely to develop hip OA due to low level of bone mineral density, secondly women's develop Hip OA due to hormonal influence and difference of hip anatomy. Moreover, females are more likely to develop Hip OA due to their poor accessibility towards health care facilities due to gender discrimination and cultural norms especially in tribal areas [1,13-15].

House hold income was the third major contributing factor which was directly related to Hip OA and the study concluded that the patients with low-income are widely affected by Hip OA. The Hip OA is more common in people with low income as they cannot afford the Mediterranean diet frequently, which somehow cures the OA. The People with low income cannot afford to visit the doctor or to take the therapeutic exercise by trained professional frequently, to cure the OA due to their low socio economic status $[2,16,17]$. 
Table 4: Comparison of demographic data vs Involvement of part.

\begin{tabular}{|c|c|c|c|}
\hline Variable & $\begin{array}{l}\text { Unilateral } \\
\text { n (\%) }\end{array}$ & $\begin{array}{c}\text { Bilateral } \\
\text { n (\%) }\end{array}$ & $P$ value \\
\hline \multicolumn{3}{|l|}{ Age group } & \multirow{4}{*}{0.001} \\
\hline $43-52$ years & $21(34.4)$ & $40(65.5)$ & \\
\hline $53-62$ years & 19(7.8) & 222(92.1) & \\
\hline 63 and more & 03(3.3) & $87(96.6)$ & \\
\hline \multicolumn{3}{|l|}{ Gender } & \multirow{3}{*}{0.008} \\
\hline Male & $28(11.2)$ & $221(88.7)$ & \\
\hline Female & $15(10.4)$ & $128(89.5)$ & \\
\hline \multicolumn{3}{|l|}{ Marital Status } & \multirow{11}{*}{0.384} \\
\hline Married & $35(10.8)$ & 287(89.1) & \\
\hline Unmarried & $08(11.4)$ & $62(88.5)$ & \\
\hline \multicolumn{3}{|l|}{ Education } & \\
\hline Uneducated & $08(12.3)$ & $57(87.6)$ & \\
\hline Religious education & 03(7.31) & $38(92.6)$ & \\
\hline Primary education & $07(19.4)$ & $29(80.5)$ & \\
\hline Matriculation & $06(12.0)$ & $44(88.0)$ & \\
\hline Intermediate & $05(9.25)$ & 49(90.7) & \\
\hline Bachelors & $10(11.1)$ & $80(88.8)$ & \\
\hline Higher & $04(6.15)$ & $52(92.8)$ & \\
\hline Occupation & & & \multirow{6}{*}{0.627} \\
\hline Government servant & $16(17.3)$ & $76(82.6)$ & \\
\hline Private & $03(4.0)$ & $71(95.9)$ & \\
\hline Un employed & $05(11.9)$ & $37(88.0)$ & \\
\hline Self employed & $09(10.4)$ & 77(89.5) & \\
\hline House wife & $10(10.2)$ & $88(89.7)$ & \\
\hline \multicolumn{3}{|l|}{ Income } & \multirow{7}{*}{0.006} \\
\hline No income & $16(12.6)$ & $110(87.3)$ & \\
\hline Won't disclose & 02(3.92) & $49(96.0)$ & \\
\hline Less than 10,000 & $02(10.0)$ & $18(90.0)$ & \\
\hline 10,000 to 20,000 & $07(12.5)$ & $49(87.5)$ & \\
\hline 20,000 to 30,000 & $08(17.0)$ & $39(2.9)$ & \\
\hline More than 30,000 & $08(8.6)$ & $84(91.3)$ & \\
\hline \multicolumn{3}{|l|}{ Locality } & \multirow{3}{*}{0.479} \\
\hline Urban & $34(13.1)$ & $224(86.8)$ & \\
\hline Rural & $09(6.7)$ & 125(93.2) & \\
\hline
\end{tabular}

The Patient who were older, belongs to female gender along with low income were highly suspectable for Hip OA. According to observation the older females with low income were found more restrictive especially in the physical activities of their daily life as compare to men $[12,18,19]$.

\section{Conclusion}

The study finalized that the people who were older, specially belongs to female gender and with low income were more prone to develop Hip OA. Patient with Hip OA were found restrictive physically, the severity of that restrictiveness were directly linked with the severity of disease and involvement of part.

\section{Recommendations}

Older age individuals, females and people with low house hold income ought to be prioritized for the early cure of Hip osteoarthritis (OA), for enhancing their physical \& functional capacity.

\section{Acknowledgements}

We acknowledge the support of hospital staff who collected the data.

\section{Author contributions}

All Authors contributed equally.

\section{References}

1. Quintana JM, Arostegui I, Escobar A, Azkarate J, Goenaga JI, et al. (2008) Prevalence of knee and hip osteoarthritis and the appropriateness of joint replacement in an older population. Arch Intern Med 168: 1576-1584. Link: https://bit.ly/3y08633

2. Haq N, Ali AA, Riffat Y, Razaque G, Nasim A, et al. (2020) PMS76 Assessment of Health-Related Quality of Life in Patients of Knee Osteoarthritis in Quetta, Pakistan. ISPOR 23: S229. Link: https://bit.ly/3jS4ZmL

3. Østerås N, Risberg MA, Kvien TK, Engebretsen L, Nordsletten L, et al. (2013) Hand, hip and knee osteoarthritis in a Norwegian population-based study-The MUST protocol. BMC Musculoskelet Disord 14: 201. Link: https://bit.ly/3E6VCYq

4. Nho SJ, Kymes SM, Callaghan JJ, Felson DT (2013) The burden of hip osteoarthritis in the United States: epidemiologic and economic considerations. J Am Acad Orthop Surg 21: S1-S6. Link: https://bit.ly/38R2Z7I

5. Günther K, Stürmer T, Sauerland S, Zeissig I, Sun Y, et al. (1998) Prevalence of generalised osteoarthritis in patients with advanced hip and knee osteoarthritis: the Ulm Osteoarthritis Study. Ann Rheum Dis 57: 717-723. Link: https://bit.ly/3kWDUhe

6. Loza E, Lopez-Gomez JM, Abasolo L, Maese J, Carmona L, et al. (2009) Economic burden of knee and hip osteoarthritis in Spain. Arthritis Rheum 61 158-165. Link: https://bit.ly/3I5765L

7. Cross M, Smith E, Hoy D, Nolte S, Ackerman I, et al. (2014) The global burden of hip and knee osteoarthritis: estimates from the global burden of disease 2010 study. Int J Surg 73: 1323-1330. Link: https://bit.ly/3BP4BeL

8. Ali AA, Sheikh N, Chughani V, Hussain A, Rafique M, et al. (2021) Comparision of Effectiveness of Isometric and Stretching Exercise in Pain Management among the Forward Head Posture Patients. 15.

9. Lu Z, Li X, Chen R, Guo CJ (2018) Kinesio taping improves pain and function in patients with knee osteoarthritis: A meta-analysis of randomized controlled trials. 59: 27-35.

10. Lequesne MG, Maheu EJ (2003) Clinical and radiological evaluation of hip, knee and hand osteoarthritis. Aging Clin Exp Res 15: 380-390. Link: https://bit.ly/3I56MUB

11. Ali AA, Naqi S, Bugti MK, Rafeeq M, MR MI, et al. (2021) Assess the awareness of COVID-19 among the physiotherapists working in different hospitals of Sindh, Pakistan: A cross sectional survey. J Nov Physiother Phys Rehabil 8: 005-009. Link: https://bit.ly/3hd6x8T

12. Guillemin F, Rat A, Mazieres B, Pouchot J, Fautrel B, et al. (2011) Prevalence of symptomatic hip and knee osteoarthritis: a two-phase population-based survey. Osteoarthritis Cartilage 19: 1314-1322. Link: https://bit.ly/38MfgKT

13. Otten R, van Roermund PM, Picavet HS (2010) Trends in the number of knee and hip arthroplasties: considerably more knee and hip prostheses due to osteoarthritis in 2030. Ned Tijdschr Geneeskd 154: A1534. Link: https://bit.ly/3tpzPWE

14. Nüesch E, Dieppe P, Reichenbach S, Williams S, Iff S, et al. (2011) All cause and disease specific mortality in patients with knee or hip osteoarthritis: population based cohort study. BMJ 342: d1165. Link: https://bit.ly/3jPDR70

15. Ali AA, Haq N, Hussain A, Rafique M, MR Ml, et al. (2021) Assessment of Frequent Work Related Musculoskeletal Disorders in Patients Visiting the Physiothrapy OPD of Civil Hospital Quetta, Pakistan: A Cross Sectional Survey. Indian Journal of Physiotherapy \& Occupational Therapy 15: 91. Link: https://bit.ly/3h8movs

Citation: Ali AA, Bhutto N, Chandio S, Waqas S, Khoso AR, et al. (2021) Association of different Demographic characteristics with Hip Osteoarthritis patients attending the different Hospitals across the Karachi and Quetta. Open J Orthop Rheumatol 6(1): 062-066. DOI: https://dx.doi.org/10.17352/ojor.00040 
16. Marks R, Allegrante JP (2001) Body mass indices in patients with disabling hip osteoarthritis. Arthritis Res 4: 112-116. Link: https://bit.ly/3DUnNtt

17. Zakaria ZF, Bakar AA, Hasmoni HM, Rani FA, Kadir SA (2009) Health-related quality of life in patients with knee osteoarthritis attending two primary care clinics in Malaysia: a cross-sectional study. Asia Pac Fam Med 8: 10. Link: https://bit.ly/3jQt7Wx
18. Dougados M, Gueguen A, Nguyen M, Berdah L, Lequesne M, et al. (1996) Radiological progression of hip osteoarthritis: definition, risk factors and correlations with clinical status. Ann Rheum Dis 55: 356-362. Link: https://bit.ly/3jUevps

19. Ali AA, Haq N, Hussain A, Rafique M, MR MI, et al. (2021) Assesment of Neck Pain Causes and Its Intensity among the Students of Department of Eastern Medicine, University of Balochistan, Quetta, Pakistan. Indian Journal of Physiotherapy \& Occupational Therapy 15: 78. Link: https://bit.ly/2Ysjkxl
Discover a bigger Impact and Visibility of your article publication with

Peertechz Publications

\section{Highlights}

* Signatory publisher of ORCID

* Signatory Publisher of DORA (San Francisco Declaration on Research Assessment)

* Articles archived in worlds' renowned service providers such as Portico, CNKI, AGRIS, TDNet, Base (Bielefeld University Library), CrossRef, Scilit, J-Gate etc.

* Journals indexed in ICMJE, SHERPA/ROMEO, Google Scholar etc.

* OAI-PMH (Open Archives Initiative Protocol for Metadata Harvesting)

* Dedicated Editorial Board for every journal

* Accurate and rapid peer-review process

* Increased citations of published articles through promotions

* Reduced timeline for article publication

Submit your articles and experience a new surge in publication services

(https://www.peertechz.com/submission).

Copyright: (C) 2021 Ali AA, et al. This is an open-access article distributed under the terms of the Creative Commons Attribution License, which permits unrestricted use, distribution, and reproduction in any medium, provided the original author and source are credited.

Citation: Ali AA, Bhutto N, Chandio S, Waqas S, Khoso AR, et al. (2021) Association of different Demographic characteristics with Hip Osteoarthritis patients attending the different Hospitals across the Karachi and Quetta. Open J Orthop Rheumatol 6(1): 062-066. DOI: https://dx.doi.org/10.17352/ojor.00040 